\title{
Testicular Cancer Pathologic Regional Lymph Nodes TNM Finding v7
}

National Cancer Institute

\section{Source}

National Cancer Institute. Testicular Cancer Pathologic Regional Lymph Nodes TNM

Finding V7. NCI Thesaurus. Code C89246.

A pathologic finding about one or more characteristics of testicular cancer, following the rules of the TNM AJCC V7 classification system as they pertain to staging of regional lymph nodes. (from AJCC 7th Ed.) 